\title{
Self Directed Learning: A Longstanding Tool for Uncertain Times
}

\author{
Donald N. Roberson Jr.1,2, Sima Zach ${ }^{3}$, Noa Choresh ${ }^{3}$, Iris Rosenthal ${ }^{4}$ \\ ${ }^{1}$ Global Scholars, Kansas City, USA \\ ${ }^{2}$ Associate Professor, Palacky University, Olomouc, Czech Republic \\ ${ }^{3}$ The Academic College at Wingate, Wingate, Israel \\ ${ }^{4}$ Beit-Berl College, Kfar Saba, Israel \\ Email: ^dnrobersonjr@gmail.com,simaz@wincol.ac.il,noa@wincol.ac.il, iris@Inet.co.il
}

How to cite this paper: Roberson Jr., D. N., Zach, S., Choresh, N., \& Rosenthal, I. (2021). Self Directed Learning: A Longstanding Tool for Uncertain Times. Creative Education, 12, 1011-1026.

https://doi.org/10.4236/ce.2021.125074

Received: April 18, 2021

Accepted: May 21, 2021

Published: May 24, 2021

Copyright $\odot 2021$ by author(s) and Scientific Research Publishing Inc. This work is licensed under the Creative Commons Attribution International License (CC BY 4.0).

http://creativecommons.org/licenses/by/4.0/

\begin{abstract}
Education has had to change and adapt due to the implications of COVID-19. The unknown dynamic about the virus has resulted in a variety of programs from school closings to more independent education. In many situations traditional classes have been closed and people have had to become more independent and self-directed. The purpose of this study is to examine more about the concept named self-directed learning (SDL). This will take place by examining two different research projects on the topic of SDL. The wide gap between these two research programs indicates the flexibility of self-directed learning to assist with the gaps due to closing many aspects of our educational systems.
\end{abstract}

\section{Keywords}

Pandemic, Self-Directed Learning, Older Adults, College Students

\section{Introduction and Literature}

COVID-19 has changed most aspects of life during 2020 and 2021. It has certainly challenged the educational systems around the world in terms of bringing together the community known as the local school system. In response, many schools have closed, some were refashioned, and almost all of them were dependent on the individual learner through on line computer lessons. On a wider scale many other non-formal schools closed and this individual learning became the precedence. From senior classes in informal settings, to college lectures, to grade school, many of the educational programs in the world have become more dependent on the individual self-learner. This is an appropriate time to refocus 
on the concept of self-directed learning (SDL). This previously popular topic was in fashion during the 1970s and garnered a great deal of interest. Despite the controversy, as well as attempts to rename or update, self-directed learning remains. This idea of learning is shown to be a model, an assumption of learning, and a process to new knowledge (van der Walt, 2019). From medical schools to helping individual students, this old fashioned idea of SDL could be the new way of learning for a different and safer world (Franch, Magudia, \& Rasheed, 2020; Mahlaba, 2020).

Research has demonstrated a strong correlation between self-directed learning (SDL), motivation, and learning achievements among students from various disciplines (Mega et al., 2014). It was also found that constructive emotions from students had a positive effect on organization of time, summary of learning materials, and preparation for tests. Positive feelings also had a beneficial effect on students' self-learning ability as well as their self-efficacy. In addition, motivation had a more positive impact on the achievements of students who used self-learning than its impact on the achievements of students who studied in the traditional way (Mega et al., 2014; Venkatesh, Croteau, \& Rabah, 2014; Wang, Shannon, \& Ross, 2013). Further, it was reported that integrating technology increased the learners' motivation and satisfaction (Wang et al., 2013; Venkatesh et al., 2014), and also that highly technological-efficient students earned higher grades (Wang et al., 2013).

The purpose of this study is to examine the concept named self-directed learning (SDL). This will take place by examining two research projects on the topic of SDL. This will include Roberson and Merriam (2005) and an extensive research project by Zach, Choresh, and Rosenthal (2018). These two research projects are 20 years apart, took place on different countries-even continents, and the participants vary in age by 60 years. The contrast of these two studies will show how SDL can fit within our changing educational system due to the impact of CV19.

Roberson and Merriam (2005) show us the importance of examining SDL due to its impact on aging, retirement, and personal health. Zach et al. focus their SDL study on students at a public university. They point out this is the way students understand how to use digital tools. Zach et al. explain that SDL is often overlooked in the public school systems, and Roberson and Merriam (2005) explain that SDL is disguised or misunderstood over the course of one's life.

Roberson and Merriam (2005) review the details of previous research on SDL. Their literature encompasses the beginning of the concept to the early 2000 . They focus on the traditional side of SDL, which is self-planned and where the individual is responsible and in control of the learning. Zach et al. relate SDL to lifelong learning, and is evident by being active, goal oriented, planned, organized, and self-controlled. They emphasize that the management of the process of learning is clearly in the hands of the student. Both research projects espouse the positive qualities of SDL. 
One of the main skills needed for teachers in order to gain lifelong professional development is self-learning (SL) (Lai, Li, \& Wang, 2017). SL (sl and SDL is the same idea) is characterized by a personal and unique learning experience that contains personal meaning, process planning, objective and applicative goal setting, and monitoring processes that represent metacognitive aspects (Huffaker \& Calvert, 2003; Nodoushan, 2012; Svinicki, 2010). This is an active learning (Nodoushan, 2012), in which the learner has to be goal-oriented, and who must demonstrate planning, organizing and self-control skills. The learner is required to discover what inspires him/her, what drives him/her to evaluate him/herself, and what are his/her inhibiting factors (Huffaker \& Calvert, 2003; Mega, Ronconi, \& De Beni, 2014; Nodoushan, 2012). In order to do so, the learner must use management and control skills, which involve process reflection and require high motivation (Nodoushan, 2012; Svinicki, 2010).

SDL can be described as intentional (Hake, 1999) and self-planned (Tough, 1979) learning, where the individual is responsible for (Brockett \& Hiemstra, 1991) and in control (Carre, 2000) of the learning. This learning can manifest itself in a variety of ways or projects from formal, informal, to nonformal, but is most often informal (Candy, 1991). "The important thing is that these projects are 'owned' by the learner who is in control of what is learned, when the learning starts, where it goes, and when it is complete" (Lamdin, 1997: p. 118). SDL can be evident by short-term projects lasting hours (Tough, 1979), as well as continuous and lifelong efforts producing experts (Cusack, 1996; Garrison, 1997).

Additional advantages of SL include the flexibility of learning in time and place, which promotes independence and accountability learning, as well as conversations and collaborations in the learning community (Platt, Amber, \& $\mathrm{Yu}, 2014)$. These researchers found that digital SDL nurtures meta-cognitive thinking and requires monitoring learning strategies, and learning pace regulation, self-discipline, responsibility, and time organizing elements.

In summary, SDL has evolved from a concept of a focused project of 7 hours (Tough, 1979) to an idea of personal responsibility in learning that can impact lives (Candy, 1991; Lawrence, 2000). SDL is an attractive, complex, and ambiguous concept that emphasizes human capacity, the potential for behavior change, and self-evaluation (Danis, 1992).

\section{Method}

Roberson and Merriam (2005) incorporate a qualitative perspective as they seek to understand the nuances of personal learning among those who are retired. They selected, or were referred to participants known for learning; a result of this research based on lengthy time with ten participants they created a graph which helps to explain more about the way older adults are learning on their own. The ten participants were all over 75, matched the racial demographics of the state, and were nominated by someone who attested to their learning. They were all from one rural county in South Georgia, USA. Three interviews took 
place with each participant within their home. Each person had to show or prove their SDL projects and explain them. The interviewer created a safe and open atmosphere so they were trusting with the information. The material went through the rigors of research; they arrived at various conclusions. These were confirmed at a member check in the area. The details of this research are in the Appendix.

Zach et al. incorporated several tools of measurement in their research. This included digital learning with various tools, written manuals, written exercises, video clips, courseware, and a computer application course. The 192 participants were all freshman at a physical education university in Israel. These 192 students participated in a self-study computer application course without a teacher. The course was based on written manuals, short films, drills, interactive courseware, and example exams. At the end of the class they were evaluated to consider the effectiveness of their individual self-directed learning. The details of this study and its results are in the Appendix.

\section{Results}

Zach et al. showed that the students acquired the information needed utilizing the concepts of SDL. In fact, 95 percent of the students passed the final exam of the class. It was also shown that students that had previous information on some of the topics scored higher. Zach et al. allowed students to explain their motive for choosing a self-learning class instead of a traditional class. Students stated that the flexible learning time, self-paced study, and a new learning approach were all important to them. It should be noted that this was the highest overall scoring of this group of students. It was the first time they incorporated self-directed learning, and all of the previous classes were in rooms with other classmates and teachers.

The research of Roberson and Merriam (2005) indicated the ten participants were involved in several SDL projects at the same time. These include genealogy, geography, Bible, computer, psychology, raising animals, community development, cooking, world events, electronics, gardening, bridge, landscaping. Each person had become a self-guided and self-learned expert in all of these areas. The researchers were shown evidence of all of these projects. The 400 pages of data from the interviews also revealed a process of learning. This begins with an incentive to learn, internal or external, if there is an interest they begin to asses resources, later they will devote systematic attention to this project, there is always some type of adjustment in their learning in order to improve the situation, and there is also a catalyst that spurs the individual to learn more, or faster. Eventually the SDL project comes to a close, or it may continue for many years.

\section{Discussion}

Zach et al. emphasize the sharp improvement that took place in the student's scores. In the previous ten years the students who took the same exam, using a 
traditional method of face to face in a classroom, made much lower scores on this exam. The students involved in the student program of self-learning improved their grades dramatically. Self-learning has been shown in this research to be an efficient method for acquiring new knowledge. Further this research indicated their students were more active or participatory during this process as well as responsible and accountable for their learning activities than in previous traditional classes.

Educators refer to scaffolding as a variety of instructional techniques used to move students progressively toward stronger understanding and, ultimately, greater independence in the learning process. Teachers provide successive levels of temporary support that help students reach higher levels of comprehension and skill acquisition that they would not be able to achieve without assistance. Like physical scaffolding, the supportive strategies are incrementally removed when they are no longer needed, and the teacher gradually shifts more responsibility of the learning process to the student. Also helpful were the ways that the participants could choose their own particular way of learning, this "scaffolding" was based around the choices of various manuals, video, and other courseware. Students chose the tools they felt would be useful for them. Further the self-learning course was chosen because it fit into the schedule of the participant, time constraints, and learning environment.

While success in a course is perceived as an achievement for both teachers and students, success in the final exam in the current study is an achievement for both the method and the students. After 10 years of colossal failure in the traditional face-to-face course with the same content, the SL course was a great success; students' grades at the end of the course improved dramatically. The student teachers had increased their knowledge in computer and information skills. As reported by others (Huffaker \& Calvert, 2003; Nodoushan, 2012; Svinicki, 2010), self-learning has been proven to be an efficient method for acquiring new knowledge. Our results support other studies' results that self-learning promotes active learning and involves responsibility and accountability for learning (Nodoushan, 2012; Platt et al., 2014), and therefore is relevant to student teachers' functionality. This indicates that innovative teaching should be adjusted to the learners so that it will increase motivation for learning and academic achievements (Wang et al., 2013; Venkatesh et al., 2014), we enabled the participants of the course to choose their way of self-learning, providing them with a variety of learning scaffoldings: written manuals, practices, video clips, and courseware. The rationale for planning the course that way was to achieve an effective teaching method for acquiring computer and information skills. Indeed, the results demonstrated that all of the students significantly increased their academic achievements, irrespective of their level of knowledge at the beginning of the course. In other words, our findings reinforced the perception that in a self-learning process students adopt and use learning habits and tools that they find useful (Wang et al., 2013), or ones that they believe contribute to their 
learning.

The late life changes of the older adults in this study are obvious throughout the process of learning and especially within the internal and external incentive, the interest to learn, and in the catalyst that spurs one to learn more. Although the participants discussed a variety of late-life changes, the dominant ones were retirement or more time, change in family, and loss. Interest in learning arises from a personal need or curiosity of the person. This need is based on the personality, background, needs (Maslow, 1970), self-image (Lawrence, 2000), and stage of life of the person (Jarvis, 2001; Kleiber, 1999; Lamdin, 1997). Kleiber (1999) discusses how the individual takes actions as a natural response to their development and that often this response is seen in self-directed learning. Lamdin (1997) also states that learning is usually initiated by some particular event in one's life. The older adults in this study were prompted to learn what was necessary to adjust to new developmental challenges associated with aging. The process of learning of these 10 participants moved from an internal or external incentive to interest in the topic to accessing resources, from systematic attention to making adjustments with the activity, and eventually a final resolution. During this process there is often a catalyst that stimulates the process. This catalyst, independent of the learner, was some external event or person who encouraged the participant to continue their learning. This catalyst occurred at differing times in the process. Close friends, children and grandchildren, and even strangers can be a catalyst. The catalyst could also be described as a late-life change such as a significant event, perhaps a tragedy, or a special occasion. The catalyst functions to encourage or provoke the learner to begin or continue to pursue an activity of learning.

The personal learning was an integral and central part of the lives of these older adults as well as the college students. Interwoven and connected throughout their activities was a natural desire to continue to learn. The findings of this research also reflect how they incorporated SDL to gain specific information to help with various adjustments brought on by their specific situations. The participants discussed the highly engaging nature of this self-directed learning as enjoyable, fun, and exciting. Participants were absorbed and focused on these personal educational activities. Knowles (1984) says, "[Learning] should be an adventure, spiced with the excitement of discovery. It should be fun" (p. 16). From Charlie's tool sheds to Thelma's gardens to Betty's books to Norman's birdfeeders, these older adults as well as college students have created places of enjoyment and learning.

The nature of this learning reflected ideas of Roberson (2004) including new and old information, deliberate and serendipitous experiences, and simple and complex topics. This SDL involved not only new material, but also old information. Each person discussed learning new topics; but they also talked about lessons from the past that have been reshaped for this particular class. Similarly, findings from this present research support discussions of educators such as 
Spear and Mocker (1984) who describe this interplay of new and old information in their research of how adults organize learning. Their research portrays a process where learning is assembled throughout one's life and from a variety of separate and unrelated settings into meaningful constructs. Spear and Mocker describe this process:

During their life spans, individuals assemble random bits of information, observations, or perceptions for no special purpose and whose retention over time is unexplained. When the decision is made to learn a skill or gain competence in a related area, the catalog of related information is the organizing factor (p. 7).

The notion of thoughts and impressions, intrusions and uninvited activities, as well as mystery and even spirituality has an important role in the process of personal learning. Each participant mentioned an unplanned or informal event that had a significant role in his or her learning. A friend gave "Wilbur" a book; this gift became the impetus for personal and informal learning about the author. Backing up these ideas are Merriam and Caffarella (1999) who provide a brief explanation of informal learning: "Informal learning refers to experiences of everyday living from which we learn something" (p. 21).

SDL is a collaborative process. Even though the name self-directed implies individual effort, there is usually the inclusion of other people. Gibbons et al.'s (1980) research on self-education revealed the following: "Self-education is best cultivated in a warm, supportive, coherent environment in which people generally are active and there is a close relationship with at least one other person" (p. 54). According to Lamdin (1997) other people such as "friends, neighbors, experts, teachers, mentors, tutors are usually involved in self-directed learning projects at some stage" (p. 120). In Tough's (1979) description of learning projects he describes how each participant sought out the opinions of others. Participants in this study emphasized how utilizing friends and experts were vitally related to their learning. For example, Thelma is always looking for ideas from others concerning new ways to decorate. Bill likes to walk around town and talk to people in the community and discover ways to help the younger generation. Charlie has skill in a variety of topics, but he will also ask the county agent or a professional electrician for more information. Sue has raised champion Dachshunds, but she also consults her veterinarian.

SDL is goal-directed. Probably the most consistent line of thought concerning SDL is that it is centered on a certain goal and objective (Knowles, 1984; Tough, 1979). Tough (1979) set a limit for the self-planned learner as an investment of seven hours toward a self-planned effort. In Israel, students were determined to get the passing mark on this test. Similarly, Lamdin's recent survey revealed that 12 hours of concentrated effort toward a particular subject warranted a self-directed learning effort. She also stated that SDL is the main way that older adults learn: 
Self-directed learning is the single most prevalent mode of learning among older adults, growing out of the learner's unique interests and needs and carried on at levels comfortable for the individual. Opportunities for self-directed learning are low cost and readily available to the physically active, the handicapped, and the homebound, irrespective of gender, race, or class (p. 162).

In closing, findings of this present research confirm that older rural adults and younger college kids were seriously involved in daily tasks of self-directed learning. This learning was seen as goal directed, and involvement with others.

\section{Conclusion and Implications}

In this reconfiguration of a school system around the world, this research indicates that self-directed learning can help to promote personal learning. Its self-reliance, independence, and personal motivation help the singular learner, trying to survive, a pandemic.

SDL programs should be incorporated into more education programs especially in grade schools and the college/university setting. This SDL program should include a variety of learning tools for the preference of the student. SDL is occurring among all ages, college students as well as seniors. The process of learning seems to be similar to both sets of studies. SDL theory is appropriate today in understanding how the individual chooses to learn. It is evident in various age groups as well as in different countries.

School age participants should be allowed to participate in SDL in their work. Appropriate tools should also be allowed to help complete the learning program. Homework may be a shadow of SDL, however, the way it is usually presented does not allow the student to be self-directed. Practitioners in every fabric of our society can incorporate the information from this research. Adult educators who work with older adults will gain insight as to how one's stage in life affects learning. Those who work closely with older adults can understand the importance of incorporating the philosophy of self-direction into one's class or program. Specifically, librarians could design a center of self-directed study utilizing their resources. Medical and educational practitioners could include self-direction into their programs; this will shed light on how self-directed learning can meet the variety of needs of the aging adult. For example, the medical community could begin to employ adult educators or adult counselors who specialize in self-directed learning. They could help each older adult craft his or her own personal project for better health from Internet resources to personal exercise projects. Another powerful dynamic of learning is one's community.

Cloaked behind the name of self-direction is a foundation and community of friends and family; book clubs, health clubs, investment clubs are based on this overlooked social dimension of learning (Wenger, 1998). In summary, this research will help practitioners learn how to encourage the skill of self-directed learning across the lifespan. Suggested further research would include the impact 
of living in urban areas, older adults who have given up on learning, and one particular demographic of the sample.

Findings show that it is possible and warranted to incorporate a self-learning course for acquiring computer and information skills into teacher education programs. The current research suggests that self-learning should include a variety of tools, both traditional and innovative, so that the students will be able to choose the most helpful and suitable one for them. We do not recommended emphasizing the use of one tool, because it was shown that student teachers use a number of tools, and consider them all as contributing to their learning process.

Older adults aged 75 to 87 indicated that SDL is often a response to developmental issues of that particular life stage. For example, generativity and health change seemed to promote SDL in all of the participants. In addition, each person continued to learn about the interests of their offspring, and their various activities promoted SDL. Several spoke about learning so they could contribute to society and the next generation. Health was a particular interest in this sample. Every pain, sickness, and prescription promoted individual efforts of learning. In each interview, the incentive to learn, the interest in learning, and a catalyst to spur the learner were related to late-life change, whether it is having more time, changes in family, or loss, both physical and social. Researchers may want to pursue this connection by investigating how other life stages shape the learning, especially self-directed learning. This study also focused on older adults in a rural setting, for we were curious how this setting would shape the process. We surprisingly found that the rural setting had a predominantly positive influence on the process. Some of the projects could only have been carried out in a rural setting. Also, the participants discussed the communal aspect of rural life such as the friendliness, helpful attitude, and most important, the accessibility of neighbors, family, and friends.

Lastly, an interesting issue is the difference in years of these two research papers. Although the height of popularity of SDL was in the late 70s, Roberson and Merriam's research took place in the late 1990s. The research and work of Zach et al., however, took place even 25 years later. Although SDL was popular, despite its criticism, it seems to have survived its critics, rather than simply being the tool of choice of privileged learners, it is the natural way to learn. Affirming this is the recent interest in this study from Israel. The purpose of this study was to elaborate on the concept of self-directed learning. The contribution to education from this research establishes the previous idea of self-directed learning. This paper reminds the reader that SDL is a valuable tool and can be seen even in variety of ages. Further this paper indicates the continued influence of student based learning with appropriate tools so they can learn in their own unique way.

\section{Conflicts of Interest}

The authors declare no conflicts of interest regarding the publication of this paper. 


\section{References}

Brockett, R. G., \& Hiemstra, R. (1991). Self-Direction in Adult Learning: Perspectives on Theory, Research, and Practice. New York: Routledge, Chapman, and Hall.

Candy, P. (1991). Self-Direction for Lifelong Learning. San Francisco, CA: Jossey-Bass.

Carre, P. (2000). From Intentional to Self-Directed Learning. In G. A. Straka (Ed.), Conceptions of Self-Directed Learning (pp. 49-57). New York: Waxman.

Cusack, S. (1996). Developing a Lifelong Learning Program: Empowering Seniors as Leaders in Lifelong Learning. Educational Gerontology, 21, 305-320. https://doi.org/10.1080/0360127950210402

Danis, C. (1992). Advances in Research and Practice in Self-Directed Learning. In G. J. Confessore, \& S. J. Confessore (Eds.), Guideposts to Self-Directed Learning (pp. 160-174). King of Prussia, PA: Organization Design and Development.

Franchi, T., Magudia, A., \& Rasheed, A. (2020). Appropriate Use of a Self-Directed Learning at Medical School Prepares Students for Future Clinical Practice. Medical Education Online, 25, Article ID: 1752450. https://doi.org/10.1080/10872981.2020.1752450

Garrison, D. R. (1997). Self-Directed Learning: Toward a Comprehensive Model. Adult Education Quarterly, 48, 18-33. https://doi.org/10.1177/074171369704800103

Gibbons, M., Bailey, A., Comeau, P., Schmuck, J., Seymour, S., \& Wallace, D. (1980). Toward a Theory of Self-Directed Learning: A Study of Experts without Formal Training. Journal of Humanistic Psychology, 20, 41-56. https://doi.org/10.1177/002216788002000205

Hake, B. (1999). Lifelong Learning in Late Modernity: The Challenges to Society, Organizations, and Individuals. Adult Education Quarterly, 49, 79-90. https://doi.org/10.1177/074171369904900201

Huffaker, D., \& Calvert, S. (2003). The New Science of Learning: Active Learning, Metacognition, and Transfer of Knowledge in E-Learning Applications. Journal of Educational Computing Research, 29, 325-334. https://doi.org/10.2190/4T89-30W2-DHTM-RTQ2

Jarvis, P. (2001). Learning in Later Life. London: Kogan Page.

Kleiber, D. (1999). Leisure Experience and Human Development: A Dialectical Interpretation. New York: Basic Books.

Knowles, M. (1984). Andragogy in Action: Applying Modern Principles of Adult Learning. San Francisco, CA: Jossey-Bass.

Lai, C., Li, X., \& Wang, Q. (2017). Students' Perceptions of Teacher Impact on Their Self-Directed Language Learning with Technology beyond the Classroom: Cases of Hong Kong and U.S. Educational Technology Research \& Development, 65, 1105-1133. https://doi.org/10.1007/s11423-017-9523-4

Lamdin, L. (1997). Elder Learning. Phoenix, AZ: The Oryz Press.

Lawrence, D. (2000). Building Self-Esteem with Adult Learners. Thousand Oaks, CA: Paul Chapman.

Mahlaba, S. C. (2020). Reasons Why Self Directed Learning Is Important in South Africa during the COVID-19 Pandemic. South African Journal of Higher Education, 34, 120-136. https://doi.org/10.20853/34-6-4192

Maslow, A. H. (1970). Motivation and Personality (2nd ed.). New York: Harper-Collins.

Mega, C., Ronconi, L., \& De Beni, R. (2014). What Makes a Good Student? How Emotions, Self-Regulated Learning, and Motivation Contribute to Academic Achievement. 
Journal of Educational Psychology, 106, 121. https://doi.org/10.1037/a0033546

Merriam, S. B., \& Caffarella, R. (1999). Learning in Adulthood: A Comprehensive Guide (2nd ed.). San Francisco, CA: Jossey-Bass.

Nodoushan, M. A. S. (2012). Self-Regulated Learning (SRL): Emergence of the RSRLM Model. International Journal of Language Studies, 6, 1-16.

Platt, C. A., Amber, N. W., \& Yu, N. (2014). Virtually the Same? Student Perceptions of the Equivalence of Online Classes to Face-to-Face Classes. Journal of Online Learning and Teaching, 10, 489-503.

Roberson, D. N. Jr. (2004). The Nature of Self-Directed Learning in Older Rural Adults. Ageing International, 29, 199-218. https://doi.org/10.1007/s12126-004-1017-0

Roberson, D. N. Jr., \& Merriam, S. B. (2005). The Self-Directed Learning Process of Older Adults. Adult Education Quarterly, 55, 269-287. https://doi.org/10.1177/0741713605277372

Spear, G. E., \& Mocker, D. W. (1984). The Organizing Circumstance: Environmental Determinants in Self-Directed Learning. Adult Education Quarterly, 35, 1-10. https://doi.org/10.1177/0001848184035001001

Svinicki, M. D. (2010). Student Learning: From Teacher-Directed to Self-Regulation. New Directions for Teaching and Learning, 2010, 73-83. https://doi.org/10.1002/tl.411

Tough, A. (1979). The Adult's Learning Projects: A Fresh Approach to Theory and Practice in Adult Learning (2nd ed.). Toronto: Ontario Institute for Studies in Education.

Van der Walt, J. L. (2019). The Term Self Directed Learning-Back to Knowles, or Another Way to Forge Ahead? Journal of Research on Christian Education, 28, 1-20. https://doi.org/10.1080/10656219.2019.1593265

Venkatesh, V., Croteau, A. M., \& Rabah, J. (2014). Perceptions of Effectiveness of Instructional Uses of Technology in Higher Education in an Era of Web 2.0. System Sciences (HICSS), 2014 47th Hawaii International Conference on System Sciences, Waikoloa, 6-9 January 2014, 110-119. https://doi.org/10.1109/HICSS.2014.22

Wang, C. H., Shannon, D. M., \& Ross, M. E. (2013). Students' Characteristics, Self-Regulated Learning, Technology Self-Efficacy, and Course Outcomes in Online Learning. Distance Education, 34, 302-323. https://doi.org/10.1080/01587919.2013.835779

Wenger, E. (1998). Communities of Practice: Learning, Meaning, and Identity. Cambridge: Cambridge University Press. https://doi.org/10.1017/CBO9780511803932

Zach, S., Choresh, N., \& Rosenthal, I. (2018). Self Learning on the College Campus. Olomouc: College of Physical Culture, Palacky University. 


\section{Appendix}

\section{Summary of Israel Study}

There were 192 physical education student teachers in their first year of study at a college of physical education and sport sciences in Israel. Students pre- intervention knowledge was assessed using a basic knowledge exam that consisted of 15 questions about basic skills in Word, PowerPoint, and Excel. In addition, the exam consisted of questions about operating system and Office applications. The exam was not anonymous, due to the study's pre-post design. Two specialists in teaching and learning technology created the exam and validated it using two ways: 1) content validity was obtained by three professional teaching and learning technologists' agreement on the exam content and wording; 2) Twenty student teachers, other than the study's participants, answered the exam and gave feedback regarding its clarity and level of difficulty.

At the end of the course, level of knowledge was assessed using a post- intervention exam that consisted of 40 questions. The time duration allocated for the exam was 90 minutes. The questionnaire was tested for reliability by means of Alpha Cronbach ( $\alpha$ 's range was .87 - .92).

Perception of the contribution of learning scaffoldings to academic achievement was assessed by an online one-scale Likert type question $(1=$ not at all; $5=$ very much). The scaffoldings were: written manuals, short films, interactive drills, interactive courseware, and example-exams. In addition, participant were asked to describe their reason for choosing the SDL course instead of face-toface traditional course. During the semester the students participated in selfstudy computer application course without a teacher. The course learning scaffoldings were: written manuals, short films, drills, interactive courseware, and example. The student teachers were divided into three groups according to their level of knowledge in the pre-course test. Differences between the three groups' academic achievements at the end of the course were examined using One Way Analysis of Variance (Uni ANOVA) and the Post Hoc Bonferroni test. In addition, a Chi square test was conducted to examine the differences between the three groups in their perception regarding the contribution of the learning scaffoldings to their academic achievement (AA). Correlations were performed between pre-course test scores and post-course test scores. Lastly, qualitative content analysis was applied on the answers to the open question regarding their reason for choosing the computerized self-directed course as opposed to the traditional face-to-face course.

Results show that all students significantly improved their knowledge from pre-course $-\mathrm{M}=51.8$ grade in points, to post-course $-\mathrm{M}=74.8$ grade in points. Ninety-five of the students passed the final exam. The second purpose of the study was to determine whether the level of pre-course knowledge points to differences in academic achievements, and to the perception of the learning scaffolding's contribution to their learning. Participants were divided into three levels according to their achievements in the pre-intervention knowledge test. The 
range of scores for the three groups in pre-intervention was as follows: beginners $=<47.36 / 100$; intermediate $=47.36-57.9 / 100$; advanced $=>57.9 / 100$. A one-way Analysis of Variance (ANOVA) that was conducted revealed significant differences between the three groups' AA- $\left(F_{(2,190)}=5.105, p=.007\right)$. Post-hoc Bonferroni test showed that beginners achieved significantly lower scores in the post-course exam compared with the students who were labeled advanced after the pre-intervention exam $(M=70.635, S . D=12.95 ; M=77.187, S . D=11.80$, respectively). No correlations were demonstrated between pre-course and post-course.

We also examined the student teachers' perceptions of the contribution of the five learning tools to their AA. A chi-square test that was employed at the end of the course showed no differences $\left(\chi^{2}(8)=8.378 ; p=.40\right)$. Even when separating the learning tools from each other in looking for the differences among the three levels of participants' AA, no significant differences were demonstrated. For example, although beginners perceived that ICTs contributed to their AA to a much lesser extent than the intermediate and advanced learners did $(7.8 \%, 21.3 \%$ and 18.60, respectively), these differences were non-significant $\left(\chi^{2}(2)=4.02 ; p\right.$ $=.134)$. Figure A1 illustrates the contribution of each learning tool as perceived by the participants.

As can be seen in Figure A1, about one-third of the learners perceived that all the learning tools contributed to their AA, while $27.50 \%, 19.70 \%$, and $16.90 \%$ of beginners, intermediate, and advanced, respectively, perceived that none of the tools contributed to their AA. For the purpose of analysis, we combined written manuals, drills, and example exams, gave them the label "traditional learning tools", and separated them from short films and interactive courseware, which received the label "ICTs learning tools". A slightly small but non-significant difference between the three groups of learners also appeared also for the traditional learning tools $(11.80 \%, 3.30 \%$, and $8.50 \%$ for beginners, intermediate, and advanced, respectively).

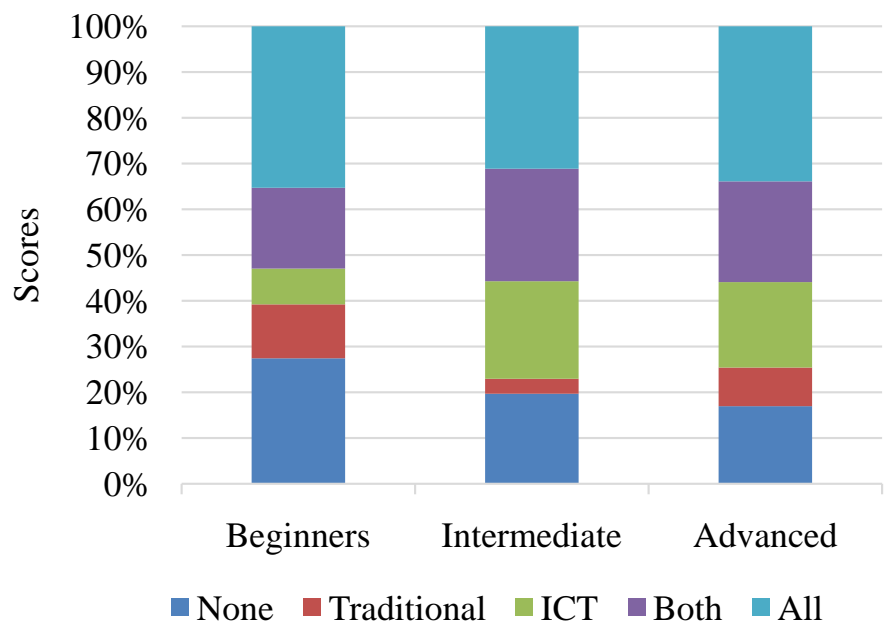

Figure A1. Differences in perception concerning the contribution of learning tools to AA among three levels of participants' pre-intervention knowledge. 
Lastly, the third purpose of the study was to explore what were the student teachers' motives for choosing self-learning as opposed to traditional face-to-face lessons with a teacher. Table A1 and Table A2 summarize the participants' answers, after sorting them to into the two main themes that emerged in the analysis. Theme one described all technical issues that the student teachers mentioned as motivators for choosing the SDL course, and theme two described all the issues student teachers mentioned regarding the learning process, habits, and self-efficacy perception. It appears from the two tables that the majority of the reasons for choosing or not choosing SDL course were technical.

Table A1. Motives for choosing ICT in the SDL approach concerning aspects of learning.

\begin{tabular}{ccc}
\hline & Learning habits & Efficacy and level of learning \\
\hline Sub-Categories & Have self-directed learning habits & Expand the existing knowledge \\
& Prefers self-directed learning strategy & Do not have to study \\
\hline
\end{tabular}

Table A2. Motives for choosing ICT in the SDL approach concerning technical aspects.

\begin{tabular}{|c|c|c|c|c|}
\hline Main Categories & \multicolumn{4}{|c|}{ Sub-categories } \\
\hline Constraints & $\begin{array}{c}\text { Appointed } \\
\text { without choice }\end{array}$ & $\begin{array}{l}\text { Face-to-face } \\
\text { course was fully } \\
\text { registered }\end{array}$ & $\begin{array}{l}\text { Appointed time for } \\
\text { registration was over }\end{array}$ & \\
\hline Time & $\begin{array}{l}\text { Requires less time } \\
\text { investment }\end{array}$ & $\begin{array}{c}\text { Flexible } \\
\text { learning time }\end{array}$ & Self-paced study & \\
\hline Schedule & $\begin{array}{c}\text { Decrease } \\
\text { schedule load }\end{array}$ & $\begin{array}{l}\text { Enable taking } \\
\text { other courses }\end{array}$ & $\begin{array}{c}\text { Hours of face-to-face } \\
\text { course are } \\
\text { inconvenient }\end{array}$ & \\
\hline $\begin{array}{c}\text { Learning } \\
\text { environment }\end{array}$ & $\begin{array}{c}\text { Quiet learning } \\
\text { environment/ } \\
\text { learning with music }\end{array}$ & $\begin{array}{l}\text { Comfortable } \\
\text { learning } \\
\text { environment }\end{array}$ & $\begin{array}{l}\text { Personal conditions } \\
\text { for learning }\end{array}$ & \\
\hline Other & The lecturer & Fun & $\begin{array}{l}\text { Wants to try a new } \\
\text { learning approach }\end{array}$ & $\begin{array}{c}\text { Tried Face-to-face } \\
\text { and failed }\end{array}$ \\
\hline
\end{tabular}

\section{Summary of research U.S.A.}

The purpose of this research was to uncover and describe the process of SDL of older, rural adults. Purposeful sampling was used in order to address the problem of this research; this is a process whereby the researcher carefully chooses participants who will provide the most relevant information. This sample was comprised of older adults who live in a rural area. A rural setting in South Georgia was chosen for this study because there is a higher percentage of older adults in rural areas, and rural areas are often overlooked in favor of more accessible urban places. Four criteria were used in selecting the participants in this study. These included the following: age, rural dwelling, diversity (race/gender), and evidence of SDL. The minimum age of the sample was set at 70 , and the ac- 
tual age range of the sample was 75 to 87 . The study took place in one county in south Georgia. This county has a total population of 16,235 with 35.9 people per square mile. This county and all of the surrounding counties are listed as rural [www.census.gov]. The sample included three African American and seven Caucasian participants matching the demographics of the state of Georgia. This included five men and five women as well as a range in education from fifth grade to Master's degree. That participants were engaged in SDL activities was ascertained in a phone call prior to the first interview (Table A3).

Table A3. Biographical information.

\begin{tabular}{|c|c|c|c|c|c|c|c|}
\hline Name & Gender & Marital & Age & Education & Work (Current/Former) & C-GC-GGC* & Race \\
\hline Robert & Male & 42 years & 75 & Two year college degree & Retired/Bookkeeper & $2(3)-4-0$ & Caucasian \\
\hline Norman & Male & Widowed & 83 & Two year college degree & Retired/Jeweler & $0(1)-1-2$ & Caucasian \\
\hline Betty & Female & 54 years & 76 & College Degree plus Certification & Retired/Librarian & $3-6-0$ & Caucasian \\
\hline Sue & Female & Widowed & 87 & One year college & Retired/Secretary & $3-7-11$ & Caucasian \\
\hline Bill & Male & Widowed & 82 & $5^{\text {th }}$ grade & $\begin{array}{l}\text { Retired/Handyman for Georgia } \\
\text { Power, Started his own business }\end{array}$ & $1(2)-3-0$ & African-American \\
\hline Hattie & Female & Widowed & 76 & High School Degree & Retired/State Mental Health Worker & $6-19-15$ & African-American \\
\hline Dora & Female & Widowed & 79 & Two year college degree & $\begin{array}{l}\text { Nursing Home Assistant/Housewife, } \\
\text { assist husband in business. }\end{array}$ & $3-8-2$ & Caucasian \\
\hline Wilbur & Male & 48 years & 75 & Sixth grade, GED Certification & Handyman & $3(5)-3$ & African-American \\
\hline Charlie & Male & 56 years & 84 & College Degree & Retired/Postal worker. & $4(5)-10-1$ & Caucasian \\
\hline Thelma & Female & Widowed & 75 & Two year college degree & Housewife & $5-11-0$ & Caucasian \\
\hline
\end{tabular}

Note. ${ }^{*}$ This indicates children-C, grandchildren-GC, and great-grandchildren-GGC. The parenthesis indicates original number. For example 3(4)-5-10(11) indicates the participant had four children originally, three are living, there are five grandchildren, originally there were 11 great-grandchildren and 10 are living.

Each participant was referred to us from a source who knew about the community including a co-operative extension agent, librarian, church staff, probate judge, and a member of the Board of Education. From a list of 25 names of potential candidates, we selected the first 10 participants who volunteered to be in the study, had the time, and met the listed criteria. Each participant was interviewed over a 2-day period in 2-hour segments. Three research questions guided the inquiry. First, participants were asked to discuss the main changes they had or were experiencing in becoming an older adult. Second, participants were asked what was important to them now and how they learned about these issues or topics. And third, they were asked to describe what it was like to live in a rural area. The data collection process was guided by the simultaneous analysis of the data. For example, after two interviews the data were transcribed and analyzed using the constant comparative method of data analysis. This analysis informed the subsequent interviews and helped to prepare us for the remainder of this research. A total of 2 months after continuous learning projects (Table A4 \& Table A5). 
Table A4. Self-directed learning activities.

$\begin{array}{cl}\text { Robert } & \begin{array}{l}\text { Robert wants to learn more about the United States through travel; he also studies } \\ \text { how the Bible relates to his life. }\end{array} \\ \text { Norman } & \begin{array}{l}\text { Norman's goal in personal learning focuses around the computer; he also wants to } \\ \text { learn more about health and aging. }\end{array} \\ \text { Sue } \quad \begin{array}{l}\text { Sue's focus of attention is raising champion dogs; she is also interested in natural } \\ \text { foods and organic gardening. }\end{array} \\ \text { Betty } \begin{array}{l}\text { One of Betty's goals is to learn how to use the computer for research; she is also } \\ \text { interested in genealogy. }\end{array} \\ \text { Bill } \quad \begin{array}{l}\text { Bill reads information that can help to improve his health; he is also learning ways to } \\ \text { help the younger generation succeed. }\end{array} \\ \text { Hattie } \begin{array}{l}\text { Hattie enjoys taking classes about the Bible; she is also learning how to improve her } \\ \text { community. }\end{array} \\ \text { Dora } \begin{array}{l}\text { One of Dora's goals is learning to improve her yard, and she is also interested in } \\ \text { learning more about nutrition and cooking. }\end{array} \\ \text { Wilbur } \quad \begin{array}{l}\text { Wilbur gives systematic attention to learning more about fire prevention, and he } \\ \text { wants to learn how to improve his town. }\end{array} \\ \text { Charlie } \quad \begin{array}{l}\text { Charlie wants to learn more about new electronics; he is also interested in personal } \\ \text { health and nutrition. }\end{array} \\ \text { Thelma } \begin{array}{l}\text { Thelma desires to learn more about the game of bridge; she also wants to learn more } \\ \text { about how to improve the community. }\end{array}\end{array}$

Table A5. Findings.

I. Nature of Self-Directed Learning
A. Highly engaging
B. Variably Structured
C. Collaborative
D. Goal-Directed
II. Process of Self-Directed Learning
A. Incentive: Internal/external
B. Interest
C. Access resources
D. Systematic attention
E. Adjustments
F. Catalyst
G. Resolution
III. Late life adjustments
A. Adjustment to time
B. Adjustment to family
C. Adjustment to loss (physical and social)
IV. Rural context
A. Positive
B. Negative

